\title{
PHYSICAL PROPERTIES OF MORINGA (Moringa oleifera) SEEDS IN RELATION TO AN OIL EXPELLER DESIGN
}

\author{
Ajav, E. $A^{1^{*}}$ and Fakayode, O. $A^{2}$ \\ ${ }^{1}$ Department of Agricultural and Environmental Engineering, University of \\ Ibadan NIGERIA. \\ ${ }^{2}$ Department of Agricultural and Food Engineering, University of Uyo NIGERIA. \\ *Corresponding Author (eaajav@yahoo.co.uk,+2348023305155).
}

\begin{abstract}
Physical properties are very important in the design and manufacturing of processing machines. In this research work, the physical properties of Moringa were determined as design parameters for the development of an oil expeller for the crop. The properties were: length, width, thickness, arithmetic and geometric diameters, surface area, sphericity, aspect ratio, moisture content, bulk and true densities, porosity, one thousand seed weight, angle of repose and coefficient of static friction. The average moisture content was found to be $7.31 \%$ wet basis. The average seed length, width and thickness were found to be $8.45,7.82$ and $6.41 \mathrm{~mm}$ respectively. The average arithmetic and geometric mean diameters were 7.560 and $7.490 \mathrm{~mm}$ respectively. The average surface area was $177.19 \mathrm{~mm}^{2}$; while the mean sphericity and aspect ratio were 0.889 and 0.9257 respectively. The average true and bulk densities were 971 and $662 \mathrm{kgm}^{-3}$ respectively and the porosity was $68.18 \%$. The mean angle of repose was $21.44^{\circ}$. The average static coefficient of friction on six different surfaces viz glass, stainless steel, mild steel, galvanized steel, rubber and plywood was found to be 1.027, 1.111, 1.376, 1.234, 2.199 and 1.607 respectively. It was found to be highest on rubber and lowest on glass. These parameters would serve as inputs for the efficient design of the oil expeller for Moringa seeds.
\end{abstract}

Keywords: Moringa, Physical Properties, Oil and Oil Expeller.

\section{INTRODUCTION}

The increasing human population pressure together with the currently growing momentum of oleo-chemicals and oil/fat derived fuels (biodiesel) cause of diminishing sources of fats and oils. In order to prevent this, it is imperative to take advantages of more and more vegetable oil to meet the growing needs of the world. This can be achieved by searching for new sources of oil, as well as exploiting sources that are currently unexploited to supplement the existing ones. The locally available oilseeds in Nigeria that have been mostly exploited include groundnut, coconut, 
soybean, sunflower seed, melon, locust bean, conophor, beniseed, cocoa bean, palm kernel, shea butter and cotton seeds (Olajide, 2000). In recent times, increased attention has been focused on the utilization of under-exploited locally available agricultural products and byproducts for food processing in developing countries. Obviously, such utilization would help these countries, especially African countries that are currently facing adverse economic problems (Olajide, 2000). Moringa oleifera is the most widely cultivated specie of the genus Moringa, which is the only genus in the family Moringaceae. There are about thirteen species of Moringa trees in the family (Price, 2007). They are native to India, the Red Sea area and/or parts of Africa. Of these species, Moringa oleifera is the most widely known. In this study, the term "Moringa" refers to Moringa oleifera. Moringa seed kernels contain a significant amount of oil that is commercially known as "Ben oil" or "Behen oil". Moringa seeds, harvested from their pods, yield approximately $35-40 \%$ of non-drying Moringa oil. The free fatty acid content varies from 0.5 to $3 \%$. The seed oil contains approximately $13 \%$ saturated fatty acids and $82 \%$ unsaturated fatty acids. It has a particularly high level of oleic acid (70\%). Other vegetable oils normally contain only about $40 \%$ oleic acid. It can be used in cooking, cosmetics, fuel and lubrications amongst others. The characteristics of Moringa oleifera seed oil can be highly desirable especially with the current trend of replacing polyunsaturated vegetable oils with those containing high amounts of monounsaturated acids (Corbett, 2003). The development of an oil expeller for the crop would enable the high potentials of the crop to be exploited and production to increase in Nigeria.

Though a number of uses for Moringa oil has been spelt out, little knowledge is available on Moringa seed oil extraction. Previous researchers have extracted Moringa oleifera oil by using methods such as solvent and aqueous enzymatic extraction. Expellers are the best technology choice for the extraction of oil from oilseeds. Methods such as water extraction and manual pressing only produce small amounts of oil; the extraction efficiencies (the percentage recovered from a possible maximum) are low and labour requirements high. Solvent extraction, while highly efficient involves very substantial capital cost and is only economic on a large scale. There is also a health and safety risk from using inflammable solvents. From the foregoing, the development of a mechanical oil expeller for Moringa becomes highly desirable. In order to design an efficient machine, the determination of the engineering properties of Moringa seeds in relation to an oil expeller design becomes important. The objective of this study was to determine the physical properties of Moringa seeds in relation to the design of an oil expeller.

\section{MATERIALS AND METHODS}

Physical properties of Moringa seeds were grouped into three namely: dimensional properties (length, width, thickness, arithmetic mean diameter, geometrical mean diameter, surface area, sphericity and aspect ratio); gravimetric properties (moisture content, true and bulk densities, porosity as well as one thousand seed weight); and frictional properties (coefficient of static friction and angle of repose). These were evaluated as design parameters for the development of an oil expeller. They were determined following standard procedures. The initial moisture content of the Moringa seeds was determined in the laboratory using the oven-dried 
method. $50 \mathrm{~g}$ of Moringa seeds were oven-dried at a constant temperature of $130^{\circ} \mathrm{C}$ for 6hours. The moisture content was calculated using equation (1):

Moisture Content (\%wet basis) $=\frac{\text { Initical weight of product }- \text { Final weight of product }}{\text { Initital weight of product }} \times 100$

One hundred Moringa seeds were randomly selected and the length, width and thickness were measured using a digital caliper with an accuracy of $0.01 \mathrm{~mm}$. The arithmetic mean diameter $\left(D_{a}\right)$, geometric mean diameter $\left(D_{g}\right)$, surface area $(S)$ and sphericity $(\Phi)$ were calculated from equations (2-5) respectively, as given by Mohsenin (1986), while the aspect ratio $\left(R_{a}\right)$ was calculated from equation (6) as given by Maduako and Faborode (1990).

$$
\begin{aligned}
& D_{a}=\frac{(L+W+T)}{3} \\
& D_{g}=(L W T)^{1 / 3} \\
& S=\pi D_{g}^{2} \\
& \Phi=\left(D_{g} / L\right) \times 100 \\
& R_{a}=(W / L) \times 100
\end{aligned}
$$

where; $L=$ length, $W=$ width, $T=$ thickness.

The true density of Moringa seeds was determined by the water displacement method. A known weight of samples was poured into a $500 \mathrm{~cm}^{3}$ fractionally graduated measuring cylinder containing $250 \mathrm{~cm}^{3}$ distilled water. The rise in water indicated the true volume of the seeds. The true density was calculated as:

True Density $=\frac{\text { Weight of the sample }}{\text { volume of water displaced }}$

The bulk density of samples was determined by using a regular container of known mass. The container was filled to the brim with the samples and was gently taped ten times for the samples to consolidate. The weights of the samples were noted and the volume of the container was estimated by filling with water, which was then poured into a $500 \mathrm{~cm}^{3}$ fractionally graduated measuring cylinders to determine the volume. The bulk density was calculated as:
BulkDensity $=\frac{\text { Weight of sample }}{\text { Volume occupied }}$ (1986).

The porosity was calculated from the bulk and true densities as given by Mohsenin

$$
\text { Porosity }=\frac{\text { True Density }- \text { Bulk Density }}{\text { True Density }} \times 100
$$

The one thousand seed weight was determined using a digital electronic balance having an accuracy of $0.001 \mathrm{~g}$. To evaluate it, one hundred seeds were randomly selected from the bulk sample and averaged. The coefficients of static friction of Moringa seeds were determined with respect to six different surfaces viz glass, stainless steel, mild steel, galvanized steel, rubber and plywood using an inclined plane apparatus as described by Dutta et al. (1988). The inclined plane was gently raised and the angle of inclination at which the samples started sliding was measured. By measuring the angle of surface $(\theta)$ at this state, the static coefficient of friction $(\mu)$ was considered as the tangent of the angle (Dutta et al., 1988).

$\mu=\tan \theta$

For the dynamic angle of repose determination, the method described by Taser et al. (2005) and Garnayak et al. (2008) was adopted. A bottomless cylinder was used, the cylinder was placed 
over a plain surface and the seeds were filled in. The cylinder was raised slowly allowing the sample to flow down and form a natural slope. The dynamic angle of repose was calculated from the height and diameter of the pile as:

$\theta=\tan ^{-1}\left(\frac{2 h}{d}\right)$

Where $\theta=$ angle of repose, $h=$ height of the pile $(\mathrm{mm})$ and $d=$ diameter of the pile $(\mathrm{mm})$.

\section{RESULTS AND DISCUSSIN}

A summary of the results of the physical properties of Moringa seeds measured is presented in Tables 1-3 for the dimensional, gravimetric and frictional properties respectively. The average moisture content was calculated as $7.31 \%$ wet basis and all the other experiments were conducted at this moisture content. The moisture content is very important as it influences the size, shape and angle of repose of the seeds; which in turn determine the hopper capacity and the free flow of the seeds.

Table 1: Dimensional Properties of Moringa Seeds

\begin{tabular}{|c|c|c|c|c|c|c|c|}
\hline $\begin{array}{l}\text { Physical } \\
\text { Properties }\end{array}$ & $\begin{array}{l}\text { No of } \\
\text { observations }\end{array}$ & $\begin{array}{l}\text { Unit of } \\
\text { measurements }\end{array}$ & $\begin{array}{l}\text { Minimum } \\
\text { Value }\end{array}$ & $\begin{array}{l}\text { Maximum } \\
\text { Value }\end{array}$ & $\begin{array}{l}\text { Mean } \\
\text { Value }\end{array}$ & $\begin{array}{l}\text { Standard } \\
\text { Deviation }\end{array}$ & $\begin{array}{l}\text { Coefficient } \\
\text { of } \\
\text { Variation }\end{array}$ \\
\hline Length & 100 & $\mathrm{~mm}$ & 6.44 & 10.68 & 8.45 & 0.976 & 11.55 \\
\hline Width & 100 & $\mathrm{~mm}$ & 5.98 & 9.91 & 7.82 & 0.922 & 11.79 \\
\hline Thickness & 100 & $\mathrm{~mm}$ & 4.11 & 7.97 & 6.41 & 1.092 & 17.04 \\
\hline $\begin{array}{l}\text { Arithmetic } \\
\text { Mean } \\
\text { Diameter }\end{array}$ & 100 & $\mathrm{~mm}$ & 5.813 & 8.963 & 7.560 & 0.866 & 11.46 \\
\hline $\begin{array}{l}\text { Geometric } \\
\text { Mean } \\
\text { Diameter }\end{array}$ & 100 & $\mathrm{~mm}$ & 5.668 & 8.782 & 7.490 & 0.880 & 11.75 \\
\hline $\begin{array}{l}\text { Surface } \\
\text { Area }\end{array}$ & 100 & $\mathrm{~mm}^{2}$ & 100.93 & 242.29 & 177.47 & 40.085 & 22.59 \\
\hline Sphericity & 100 & - & 0.750 & 0.969 & 0.888 & 0.052 & 5.86 \\
\hline $\begin{array}{l}\text { Aspect } \\
\text { Ratio }\end{array}$ & 100 & - & 0.735 & 0.986 & 0.927 & 0.050 & 5.39 \\
\hline
\end{tabular}


Table 2: Gravimetric Properties of Moringa Seeds

\begin{tabular}{|c|c|c|c|c|c|c|c|}
\hline $\begin{array}{l}\text { Physical } \\
\text { Properties }\end{array}$ & $\begin{array}{l}\text { No of } \\
\text { observations }\end{array}$ & $\begin{array}{l}\text { Unit of } \\
\text { measurements }\end{array}$ & $\begin{array}{l}\text { Minimum } \\
\text { Value }\end{array}$ & $\begin{array}{l}\text { Maximum } \\
\text { Value }\end{array}$ & $\begin{array}{l}\text { Mean } \\
\text { Value }\end{array}$ & $\begin{array}{l}\text { Standard } \\
\text { Deviation }\end{array}$ & $\begin{array}{l}\text { Coefficient } \\
\text { of } \\
\text { Variation }\end{array}$ \\
\hline $\begin{array}{l}\text { Moisture } \\
\text { Content }\end{array}$ & 3 & $\%$ wet basis & 6.97 & 7.58 & 7.31 & 0.312 & 4.27 \\
\hline $\begin{array}{l}\text { True } \\
\text { Density }\end{array}$ & 10 & $\mathrm{~g} / \mathrm{cm}^{3}$ & 0.721 & 1.071 & 0.971 & 0.105 & 10.81 \\
\hline Bulk Density & 10 & $\mathrm{~g} / \mathrm{cm}^{3}$ & 0.630 & 0.692 & 0.662 & 0.026 & 3.93 \\
\hline Porosity & - & $\%$ & - & - & 68.18 & - & - \\
\hline $\begin{array}{l}\text { One } \\
\text { Thousand } \\
\text { Seed } \\
\text { Weight }\end{array}$ & 10 & $g$ & 234.00 & 246.00 & 239.20 & 3.084 & 1.29 \\
\hline $\begin{array}{l}\text { Table 3: Fr } \\
\text { Physical } \\
\text { Properties }\end{array}$ & $\begin{array}{l}\text { tional Proper } \\
\text { No of } \\
\text { observations }\end{array}$ & $\begin{array}{l}\text { Ies of Moring } \\
\text { Unit of } \\
\text { measurements }\end{array}$ & $\begin{array}{l}\text { Minimum } \\
\text { Value }\end{array}$ & $\begin{array}{l}\text { Maximum } \\
\text { Value }\end{array}$ & $\begin{array}{l}\text { Mean } \\
\text { Value }\end{array}$ & $\begin{array}{l}\text { Standard } \\
\text { Deviation }\end{array}$ & $\begin{array}{l}\text { Coefficient } \\
\text { of } \\
\text { Variation }\end{array}$ \\
\hline 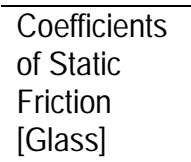 & 10 & 0 & 0.932 & 1.192 & 1.027 & 0.072 & 7.01 \\
\hline $\begin{array}{l}\text { Coefficients } \\
\text { of Static } \\
\text { Friction } \\
\text { [Stainless } \\
\text { steel] }\end{array}$ & 10 & 0 & 1.036 & 1.150 & 1.111 & 0.036 & 3.24 \\
\hline $\begin{array}{l}\text { Coefficients } \\
\text { of Static } \\
\text { Friction [Mild } \\
\text { steel] }\end{array}$ & 10 & 0 & 1.235 & 1.600 & 1.376 & 0.111 & 8.07 \\
\hline $\begin{array}{l}\text { Coefficients } \\
\text { of Static } \\
\text { Friction } \\
\text { [Galvanized } \\
\text { steel] }\end{array}$ & 10 & 0 & 1.000 & 1.428 & 1.234 & 0.174 & 14.10 \\
\hline $\begin{array}{l}\text { Coefficients } \\
\text { of Static } \\
\text { Friction } \\
\text { [Rubber] }\end{array}$ & 10 & o & 1.881 & 2.605 & 2.199 & 0.265 & 12.05 \\
\hline $\begin{array}{l}\text { Coefficients } \\
\text { of Static } \\
\text { Friction } \\
\text { [Plywood] }\end{array}$ & 10 & 0 & 1.327 & 1.963 & 1.607 & 0.257 & 15.99 \\
\hline $\begin{array}{l}\text { Angle of } \\
\text { Repose }\end{array}$ & 10 & 0 & 20.46 & 22.66 & 21.44 & 0.745 & 3.47 \\
\hline
\end{tabular}


The average seed length, width and thickness were found to be $8.45 \pm 0.976 \mathrm{~mm}, 7.82 \pm 0.922 \mathrm{~mm}$ and $6.41 \pm 1.092 \mathrm{~mm}$ respectively. Reported values for the length, width and thickness (in that order) of other oil-bearing crops were $56.18+8.64 \mathrm{~mm}, 37.89+3.82 \mathrm{~mm}$ and $12.01+1.66 \mathrm{~mm}$ for Oil bean seeds (Asoegwu, 2006); 10.63-11.09mm, 7.27-7.99mm and 6.02-7.41mm for Castor bean seeds (Shafiee et al., 2009); 12.81-14.50mm, 7.02-8.42mm, 2.22-2.49mm for Melon seeds (Davies, 2009); 2.5mm, 1.6mm and 0.94mm for Sesame seeds (Arafa, 2007); 11.21_ 1.60mm, $7.56 \pm 0.94 \mathrm{~mm}, 6.93 \pm 0.77 \mathrm{~mm}$ for Groundnut kernels (Olajide, 2000); 31.50 $0.28 \mathrm{~mm}, 23.70 \pm$ $0.20 \mathrm{~mm}$ and $22.00 \pm 0.24 \mathrm{~mm}$ for Sheanut kernels (Olajide, 2000 ); $3.34 \mathrm{~mm}, 2.13 \mathrm{~mm}$ and $0.80 \mathrm{~mm}$ for Beniseeds (Olayanju, 2002); $58.87 \mathrm{~mm}, 18.96 \mathrm{~mm}$ and $15.64 \mathrm{~mm}$ for Fennel seeds (Ahmadi et al., 2009); 12.14-12.57mm, 5.79-6.38mm, 3.86-4.09mm for Sunflower seeds (Seifi and Alimardani, 2010); 7.27- 7.81mm, 3.50-3.79mm and 2.80-3.50mm for Safflower seeds (Aktas et al., 2006); 7.27-8.25mm, 6.48-6.97mm, 5.41-5.94mm for Soybean grains (Tavakoli et al., 2009) and 17.01-17.71mm, 10.74-11.23mm, 8.19-8.16mm for Jatropha seeds (Bamgboye and Adebayo, 2012). Comparatively, it would be observed that Moringa seeds are smaller in size to all the abovementioned seeds except Sesame, Safflower, Soybean and Beniseeds. Also, the width is in the same range as that of Castor bean and Melon seeds, but slightly wider than Groundnut kernels. Furthermore, the thickness is in the same range as that of Castor bean seeds, but slighty lower than Groundnut kernels. The thickness is also lower than Sheanut kernels, Fennel, Jatropha and Oil bean seeds, but higher than Melon, Sesame, Sunflower, Safflower, Soybean and Beniseeds. The Oil bean seeds are approximately seven times longer, five times wider and two times thicker than Moringa seeds. The Sheanut kernels are approximately four times longer, three times wider and three times thicker than Moringa seeds, while the Fennel seeds are approximately seven times longer, two times wider and thicker than Moringa seeds. The arithmetic mean diameter and geometric mean diameter were $7.560 \pm 0.866 \mathrm{~mm}$ and $7.51 \pm 0.880 \mathrm{~mm}$ respectively. The surface area was $177.19 \pm 40.08 \mathrm{~mm}^{2}$; while the sphericity and aspect ratio were $0.889 \pm 0.052(88.9 \%)$ and $0.9257 \pm 0.050$ (92.57) respectively. Garnayak et al. (2008) considered any grain, fruit and seed as spherical when the sphericity value is above $70 \%$, thus, the high sphericity of the Moringa seeds is indicative of the shape towards being a sphere. This value is higher than those reported for other oil-bearing crops viz 0.523 \pm 0.065 for Oil bean seeds (Asoegwu, 2006); 0.69-0.73 for Castor bean seeds (Shafiee et al., 2009); 0.47-0.53 for Melon seeds (Davies, 2009); 0.63 for Sesame seeds (Arafa, 2007); 0.76 for Groundnut kernels (Olajide, 2000); 0.80 for Sheanut kernels (Olajide, 2000); 0.52-0.55 for Beniseeds (Olayanju, 2002); 0.45 for Fennel seeds (Ahmadi et al., 2009); 0.53-0.55 for Sunflower seeds (Seifi and Alimardani, 2010); 0.47-0.49 for Safflower seeds (Aktas et al., 2006) and 0.672-0.0.684 for Jatropha seeds (Bamgboye and Adebayo, 2012). However, it is in the same range as Soybean grains $(0.847-0.873)$ and Canola seeds $(0.82-0.93)$ as reported by Tavakoli et al. (2009) and Razavi et al. (2009) respectively. Figures 1-8 show the frequency distribution of the dimensional properties for the hundred samples of Moringa seeds measured. The values of the dimensions of the Moringa seeds are useful in the calculation of the amount of seeds that will be crushed at the feed end portion of the machine. It also assists in determining the total force that will be required to express the oil based on the number of seeds to be processed per batch. 


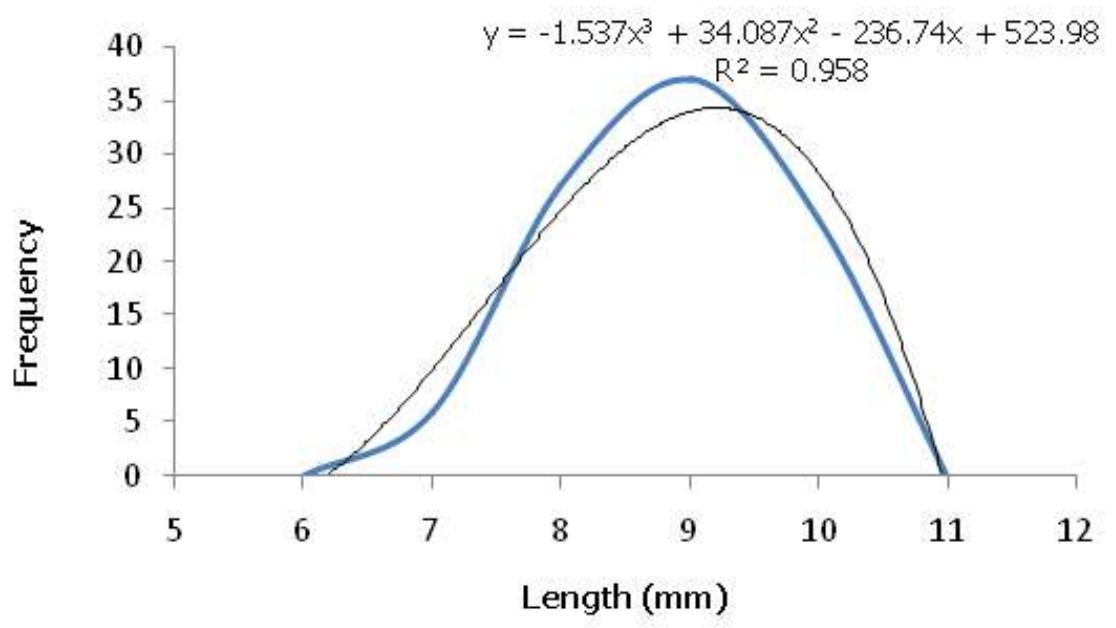

Figure 1: Frequency Distribution of the Length of Moringa Seeds

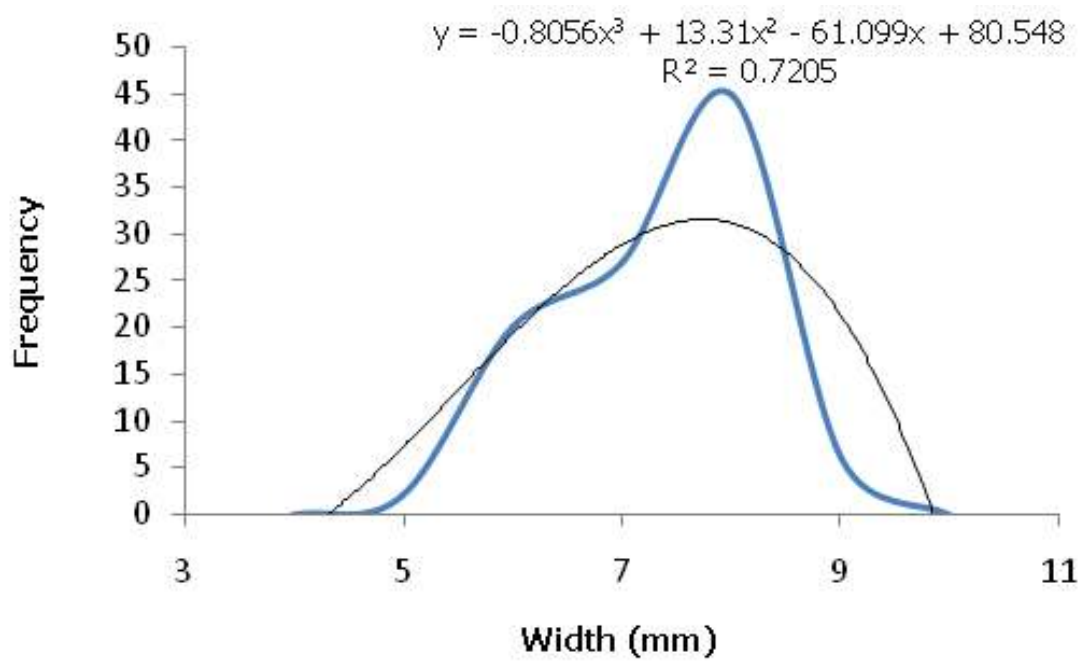

Figure 2: Frequency Distribution of the Width of Moringa Seeds. 


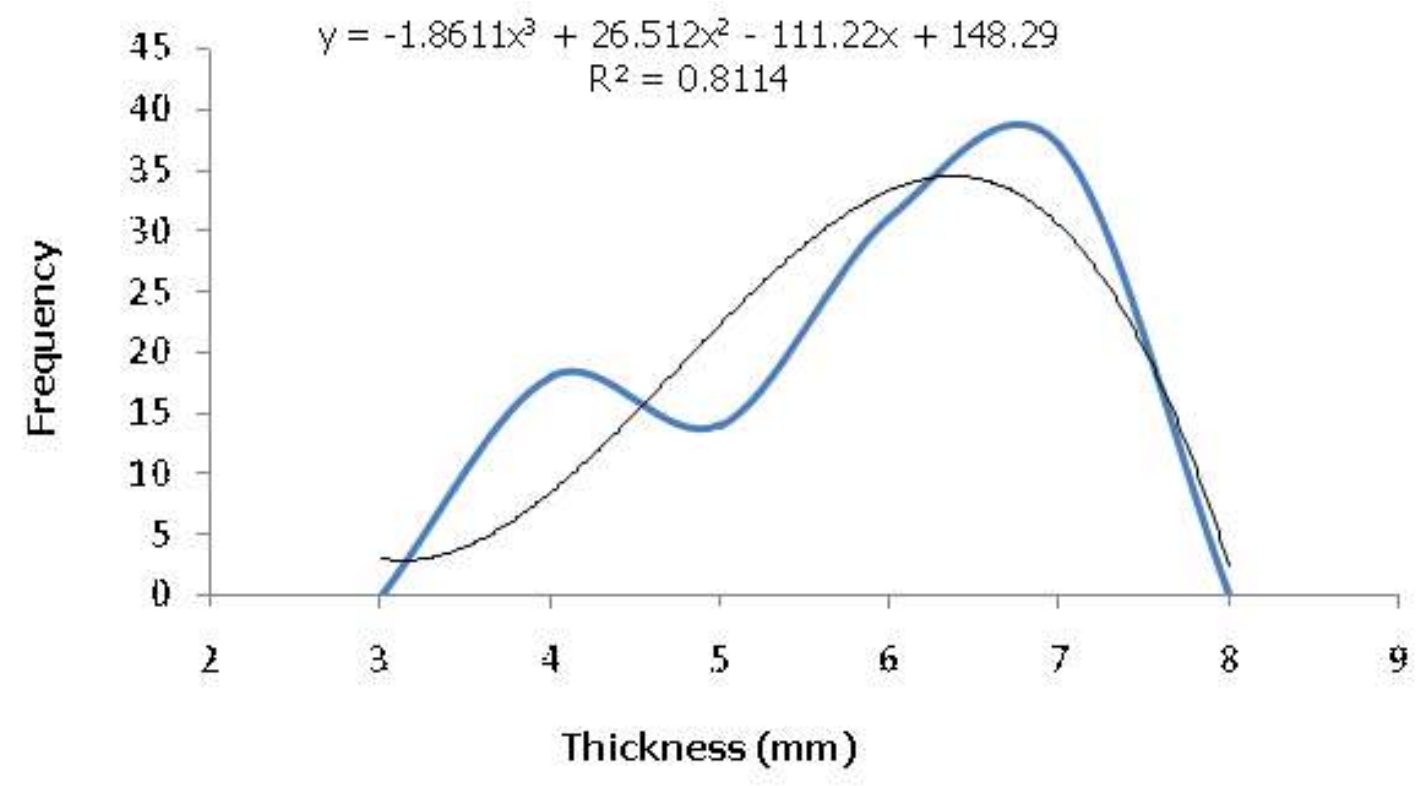

Figure 3: Frequency Distribution of the Thickness of Moringa Seeds.

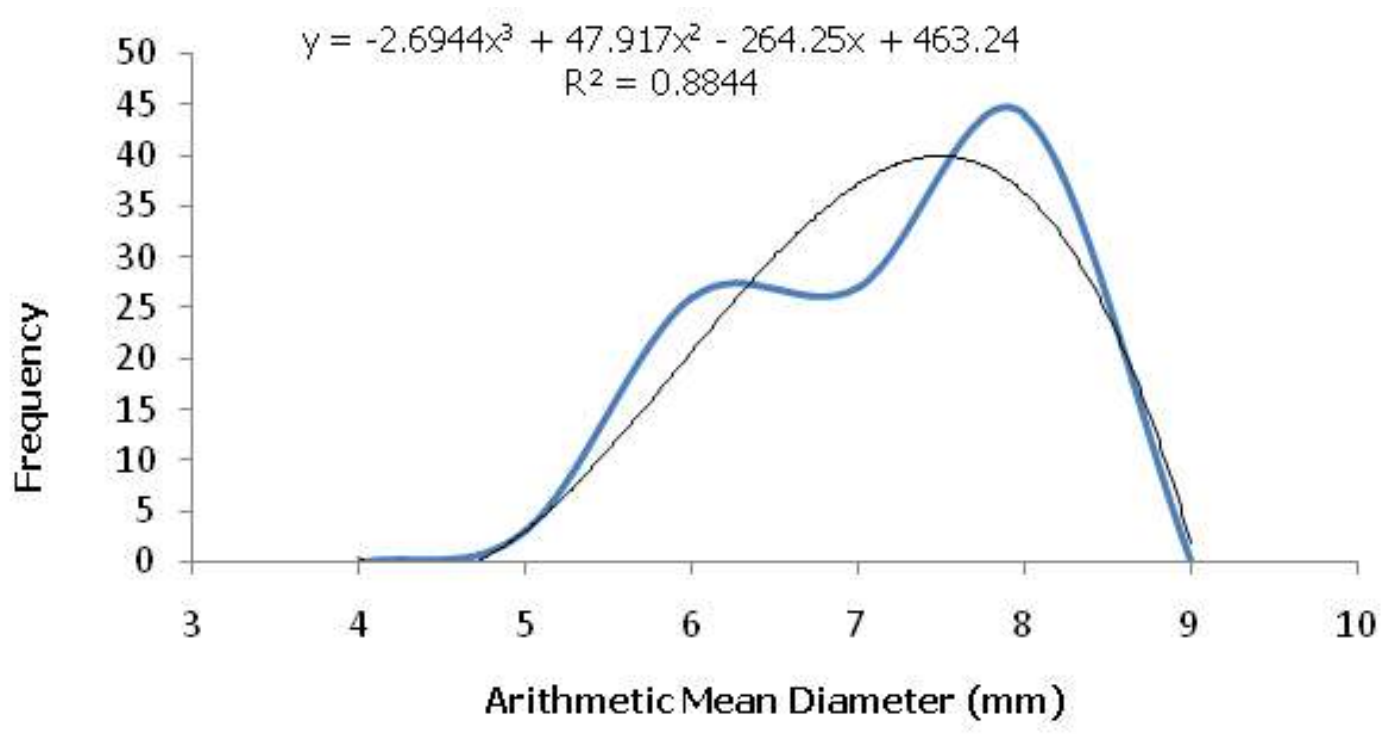

Figure 4: Frequency Distribution of the Arithmetic Mean Diameter of Moringa 


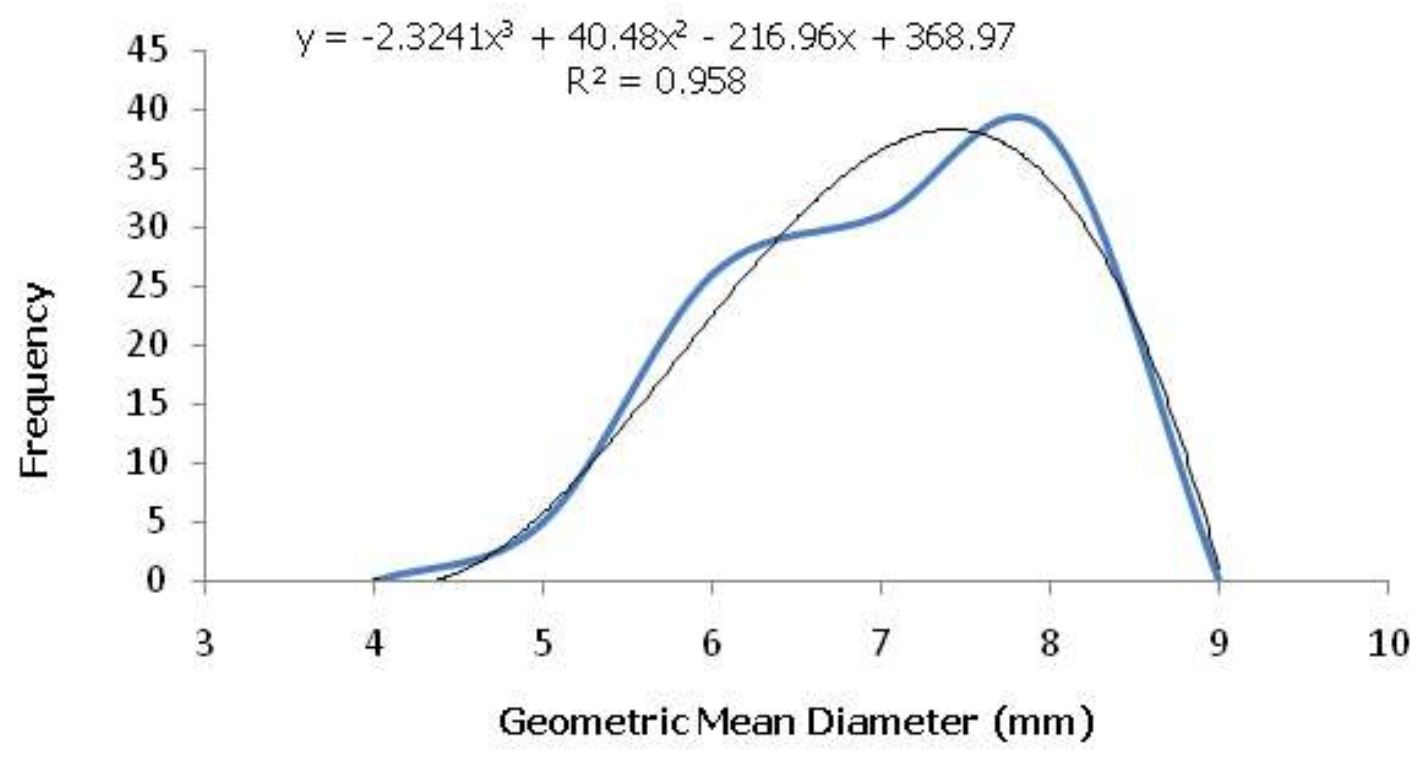

Figure 5: Frequency Distribution of the Geometric Mean Diameter of Moringa Seeds.

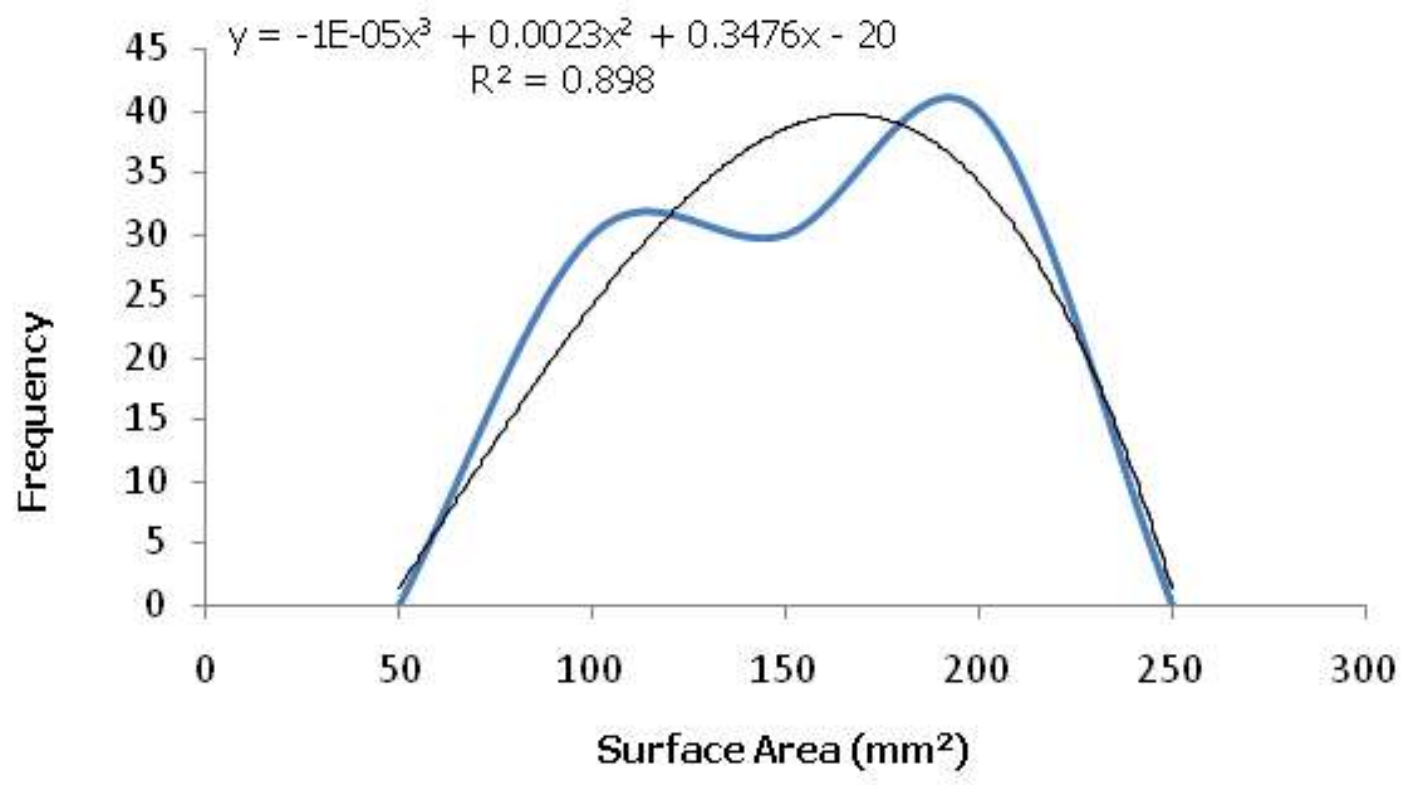

Figure 6: Frequency Distribution of the Surface Area of Moringa Seeds. 


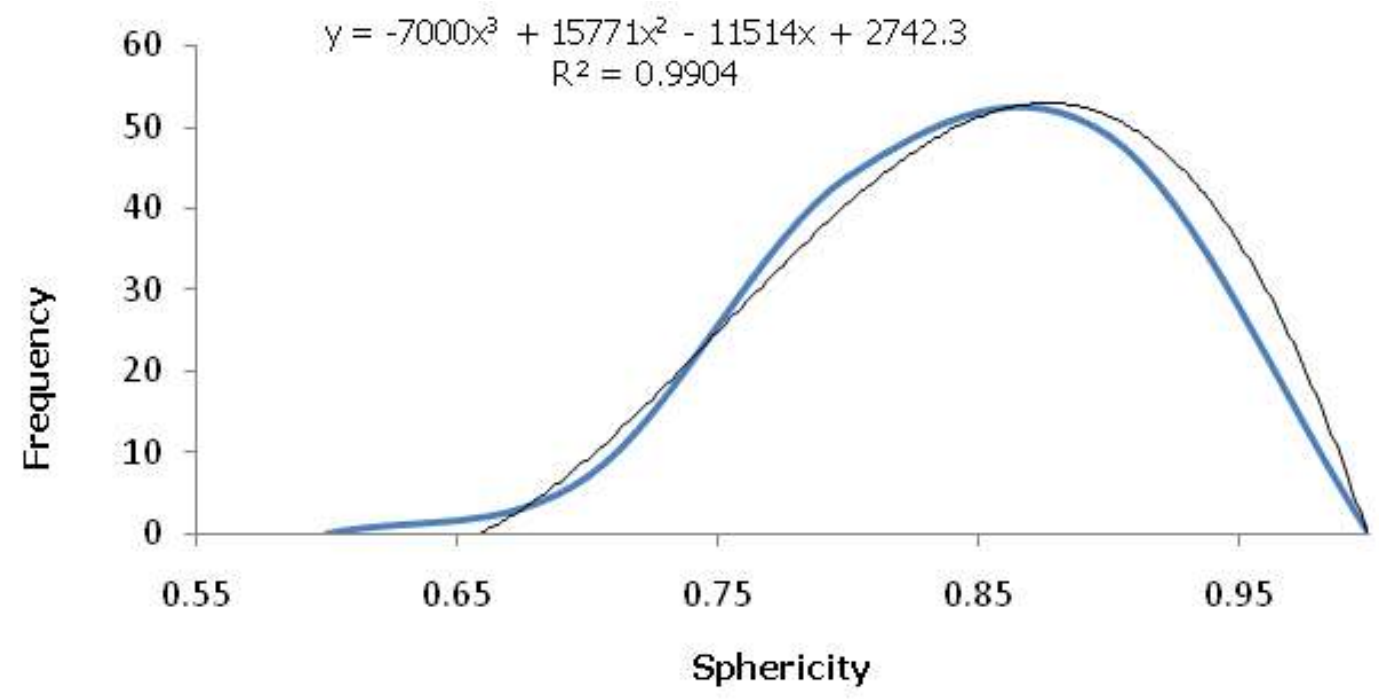

Figure 7: Frequency Distribution of the Sphericity of Moringa Seeds.

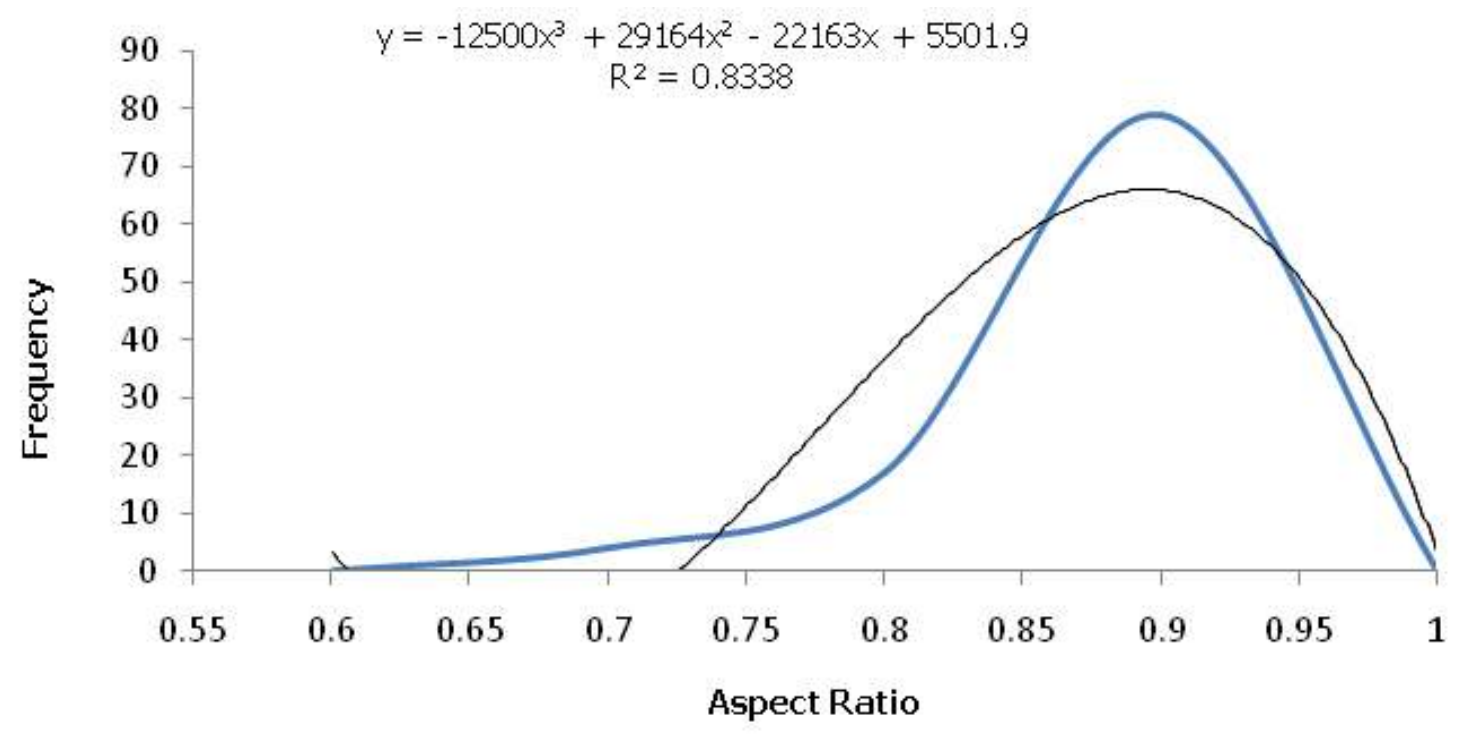

Figure 8: Frequency Distribution of the Aspect Ratio of Moringa Seeds. 


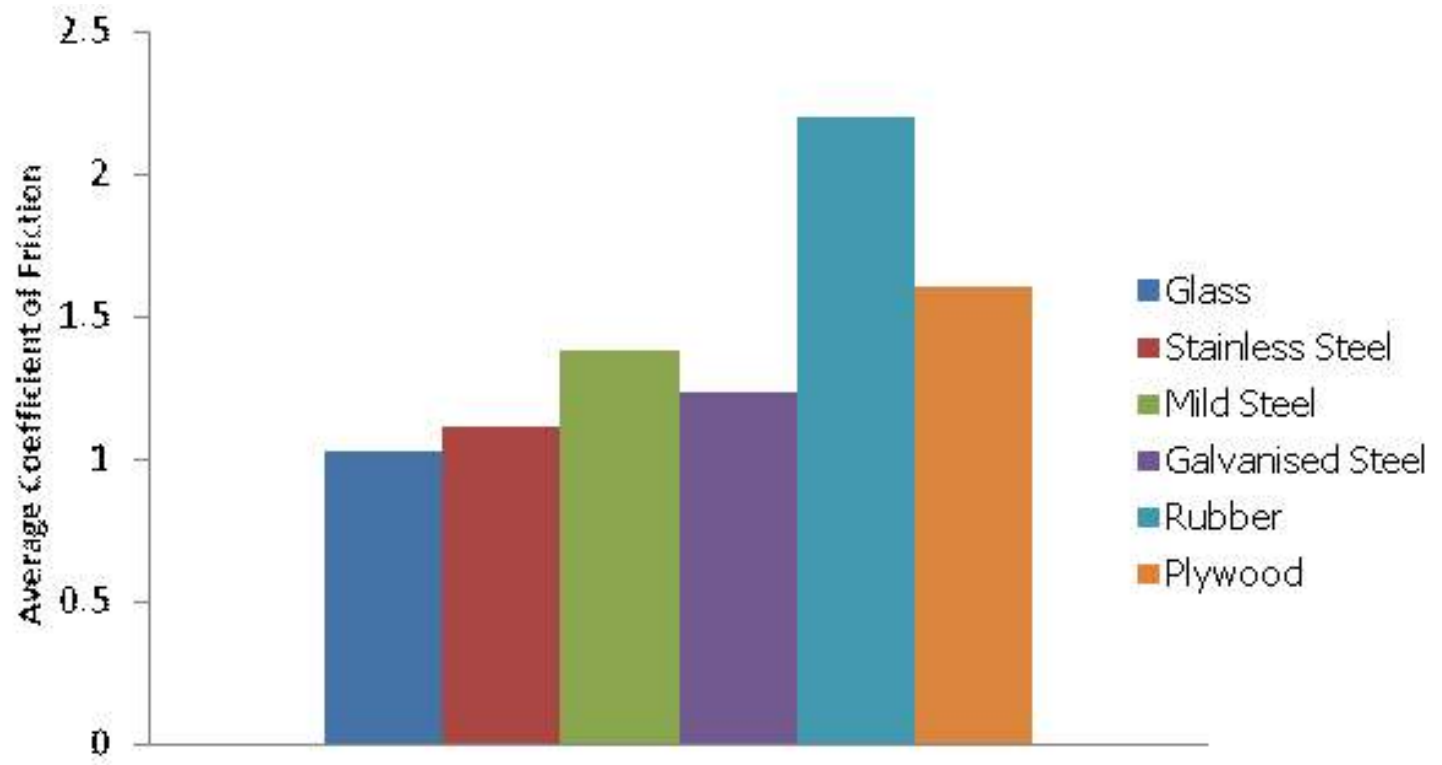

Surfaces

Figure 9: Coefficient of Friction of Moringa on different surfaces.

The average true and bulk densities were found to be $0.971 \mathrm{gcm}^{-3}\left(971 \mathrm{kgm}^{-3}\right)$ and $0.662 \mathrm{gcm}^{-3}\left(662 \mathrm{kgm}^{-3}\right)$ respectively, while the porosity was computed from the values of the true and bulk densities using equation (9) as $68.18 \%$. The true density of the Moringa seeds showed that the seeds are slightly less dense than water and therefore will float on water. Comparatively, the true density is in the same range as those reported for Sunflower seeds, $740-980 \mathrm{kgm}^{-3}$ (Seifi and Alimardani, 2010) and Jatropha seeds, $863-1035 \mathrm{kgm}^{-3}$ (Bamgboye and Adebayo, 2012); but higher than those reported for Castor bean seeds, 704.75-761.74kgm (Shafiee et al., 2009); Melon seeds, 816.09-847.47 $\mathrm{kgm}^{-3}$ (Davies, 2009); Sesame seeds, 542.1- $607.3 \mathrm{kgm}^{-3}$ (Darvishi, 2012); Fennel seeds, 889.08-937.98 $\mathrm{kgm}^{-3}$ (Ahmadi et al., 2009) and Safflower seeds, 776$780 \mathrm{kgm}^{-3}$ (Aktas et al., 2006); and lower than those reported for Groundnut kernels, $1010 \mathrm{kgm}^{-3}$ (Olajide, 2000); Beniseeds, 981-1042 $\mathrm{kgm}^{-3}$ (Olayanju, 2002), Sheanut kernels, $1170 \mathrm{kgm}^{-3}$ (Olajide, 2000) and Soybean grains, 1126.43-1147.86 $\mathrm{kgm}^{-3}$ (Tavakoli et al., 2009). Comparatively, the bulk density is higher than those reported for Oil bean seeds, $588 \mathrm{kgm}^{-3}$ (Asoegwu, 2006); Castor bean seeds, 434.75-447.50 $\mathrm{kgm}^{-3}$ (Shafiee et al., 2009); Melon seeds, 405-543 $\mathrm{kgm}^{-3}$ (Davies, 2009); Sesame seeds, $640 \mathrm{kgm}^{-3}$ (Arafa, 2007); Groundnut kernels, $479.28 \mathrm{kgm}^{-3}$ (Davies, 2009); Beniseeds, 613- 688 $\mathrm{kgm}^{-3}$ (Olayanju, 2002); Fennel seeds, 413.51$352.39 \mathrm{kgm}^{-3}$ (Ahmadi et al., 2009); 380-410 $\mathrm{kgm}^{-3}$ for Sunflower seeds (Seifi and Alimardani, 2010); Safflower seeds, $520-547 \mathrm{kgm}^{-3}$ (Seifi et al., 2010); Soybean, 625.36-650.95kgm 
${ }^{3}$ (Tavakoli et al., 2009) and Jatropha seeds, 428-474kgm ${ }^{-3}$ (Bamgboye and Adebayo, 2012). The densities are useful in the theoretical calculation of the capacity of the expeller.

The average one thousand seed weight was found to be $239.20 \mathrm{~g}$. Corresponding values for other oil bearing seeds revealed that Moringa seeds are heavier than Sunflower seeds, 80.396.8g (Seifi and Alimardani, 2010); Safflower seeds, 52.68-68.8g (Aktas et al., 2006); Melon seeds, 94.0- 110.0g (Davies, 2009); Soybean grains, 171.50-219.04g (Tavakoli et al., 2009). However, other oil bearing seeds which are heavier than Moringa seeds include Castor bean seeds, 401.0-468.8g (Shafiee et al., 2009) and Jatropha seeds, 515.4-692.6g (Bamgboye and Adebayo, 2012). One point worthy of note however that is the one thousand seed weight is a function of the individual mass (weight) of the seed/kernel/grain of the crops.

The average coefficients of friction on six different surfaces viz glass, stainless steel, mild steel, galvanized steel, rubber and plywood were found to be 1.027, 1.111, 1.376, 1.234, 2.199 and 1.607 in that order as shown in Figure 9. It would be observed that the static coefficient of friction was highest on rubber and lowest on glass. This was in agreement with earlier reports on other oil bearing seeds by Shafiee et al. (2009) on Castor bean seeds, Davies (2009) on Groundnut kernels, Davies (2010) on Melon, Olayanju (2002) on Beniseeds, Tavakoli et al. (2009) on Soybean grains andKaraj and Müller (2010) as well as Bamgboye and Adebayo (2012) on Jatropha seeds, amongst others. It was observed that the smoother the structural surface, the lower the coefficient of friction of the Moringa seeds on the surface. The knowledge of the coefficient of friction will be useful during the calculations of the various forces required to translate and compress the seeds as well as the frictional force resulting from the screw's motion. The mean angle of repose was found to be $21.44 \pm 0.745^{\circ}$. Comparatively, it is in the range of Sesame seeds, $20.16-28.67^{\circ}$ ((Darvishi, 2012). Also, it is higher than the values reported for Groundnut kernels, $17.0^{\circ}$ (Olajide, 2000); and lower than those values reported for Castor bean seeds, 30.2-34. $8^{\circ}$ (Shafiee et al. , 2009); Fennel seeds, 36.33-48.66 (Shafiee et al., 2010); Melon seeds, 29.7-36 (Davies, 2009); Sheanut kernels, $34.0^{\circ}$ (Olajide, 2000); Soybean grains, 24.56$29.93^{\circ}$ (Tavakoli et al., 2009), Sunflower seeds, $41-57^{\circ}$ (Seifi and Alimardani, 2010); Safflower seeds, $47-56^{\circ}$ (Seifi et al., 2010) and Jatropha seeds, 28-36 (Bamgboye and Adebayo, 2012). The lower angle of repose was due to the high sphericity value obtained for Moringa seeds compared to the other oil bearing seeds, making Moringa seeds to flow more easily than most oil bearing crops. The angle of repose will determine the angle at which chutes must be positioned in order to achieve consistent flow of materials through the chute. To ensure free flow, an angle of repose which is modestly higher than the average angle of repose $\left(21.44 \pm 0.745^{\circ}\right)$ obtained for the Moringa seeds would be used.

Overall, handling losses during cleaning and oil expression will be affected by the size and shape of Moringa seeds. According to Olayanju (2002), if the screen hole is too big, it may result in uncleaned seeds and if the screen hole is too small, it may lead to reduced efficiency. Y $f$ the oil barrel clearance is too big, it may result in partial crushing of seeds and if it is too small, it may lead to excessive choking of the discharge section as the seeds are crushed. For optimum performance of the cleaner and oil expeller, the size of perforations and barrel clearance have to 
be carefully selected (Olayanju, 2002). The obtained results from the dimensional properties determination are therefore very important. The sphericity will be useful in handling operations such as conveying and discharge from chutes. Since the seeds are to be transferred from one placement unit to the other, the sphericity value obtained will be taken into consideration for designing the slope of the transfer unit. The bulk density is important in calculating thermal properties in heat transfer processes, in determining Reynolds number in pneumatic and hydraulic handling of the material, in separating the product from undesirable materials and in predicting physical structures and chemical composition (Olayanju, 2002). The porosity gives knowledge of the percentage void of the Moringa seeds and is important in heat and airflow studies.

\section{CONCLUSION}

The physical properties of Moringa seeds in relation to the design of an oil expeller for the crop have been determined. The average moisture content was found to be $7.31 \%$ wet basis. The average seed length, width and thickness were found to be $8.45,7.82$ and $6.41 \mathrm{~mm}$ respectively. The mean arithmetic mean diameter, geometric mean diameter, surface area, sphericity and aspect ratio were found to be $7.560 \mathrm{~mm}, 7.490 \mathrm{~mm}, 177.19 \mathrm{~mm}^{2}, 0.889$ and 0.9257 in that order. The true density, bulk density and porosity were $971 \mathrm{kgm}^{-3}, 662 \mathrm{kgm}^{-3}$ and $68.18 \%$ respectively. The mean angle of repose was $21.44^{\circ}$, while the average static coefficients of friction on six different surfaces viz glass, stainless steel, mild steel, galvanized steel, rubber and plywood were $1.027,1.111,1.376,1.234,2.199$ and 1.607 respectively. These parameters would serve as inputs for the efficient design of the oil expeller for Moringa seeds.

\section{REFERENCES}

Ahmadi, H., Mollazade, K., Khorshidi, J., Mohtasebi, S.S. and A. Rajabipour (2009).Some Physical and Mechanical Properties of Fennel Seed (Foeniculum vulgare). Journal of Agricultural Science, Vol. 1, No. 1, pp 66-75.

Aktas, T., I. Celen and R. Durgut (2006).Some Physical and Mechanical Properties of Safflower Seed (Carthamus tinctorius L.). Journal of Agronomy, 5(4): 613-616.

Arafa, G.K. (2007). Some Physical and Mechanical Properties of Sesame Seeds concerning the selection of Separation Unit. Misr. J. Ag. Eng., 24(2): 415-429.

Asoegwu, S., Ohanyere, S., Kanu, O. and C. Iwueke (2006). "Physical Properties of African Oil Bean Seed (Pentaclethra macrophylla)" Agricultural Engineering International: the CIGR Ejournal. Manuscript FP 05 006. Vol. VIII. August, 2006. Pp 1-16. 
Bamgboye, A. I. and S. E. Adebayo (2012).Seed moisture dependent on Physical and Mechanical properties of Jatropha curcas. Journal of Agricultural Technology, Vol. 8(1): 13-26.

Corbett, P. (2003). It is time for an oil change! Opportunities for high oleic vegetables oils. Inform 14: 480481.

Darvishi, H. (2012). Moisture-Dependent Physical and Mechanical Properties of White Sesame Seed.American-Eurasian J. Agric. \& Environ. Sci., 12(2): 198-203.

Davies, R. M. (2009). Some Physical Properties of Groundnut Grains. Research Journal $\quad$ o $f$ Applied Sciences, Engineering and Technology 1(2): 10-13.

Davies, R.M. (2010). Engineering Properties of Three Varieties of Melon Seeds as Potentials for Development of Melon Processing Machines. Advance Journal of Food Science and Technology 2(1):63-66.

Dutta, S. K.; Nema V. K. and Bhardwaj R. K. (1988). Physical properties of grain. J. of Agr. Eng. Res. 39, 259-268.

Garnayak, D. K., Pradhan, R. C. Nalk, S.N. and Bhatnagar, N. (2008). Moisture-dependent physical properties of Jatropha seed. Indust. Crops Prod., 27:127-129.

Gupta, R. K. and Das, S. K. (2000). Fracture resistance of Sunflower seed and kernel to compressive loading. Journal of Food Engineering, vol.46, pp.1-8.

Karaj, S. and Müller, J. (2010). Determination of Physical, Mechanical and Chemical Properties of Seeds and Kernels of Jatropha curcas L. Ind. Crops Prod.doi:10.1016/j.indcrop.2010.04.001.

Maduako, J. N. and Faborode, M. O. (1990).Some Physical Properties of Cocoa Pods in relation to primary processing. Ife Journal of Technology, 2: 1-7.

Mohsenin, N. N. (1970). Physical Properties of Plant and Animal Materials.1st edition; Gordon and Breach Science Publishers, New York.

Mohsenin, N. N. (1986). Physical properties of Plant and Animal Materials.2nd edition; Gordon and Breach Science Publishers, New York. 
Price, M. L. (2007). The Moringa Tree. ECHO Technical Notes, USA. Pp. 1-19.

Olajide, J. O. (2000). Process Optimization and Modelling of Oil Expression from Groudnut and Sheanut Kernels. Ph.D Thesis, Department of Agricultural Engineering, University of Ibadan, Ibadan, Nigeria.

Olayanju, T. M. A. (2002). Design, Fabrication and Evaluation of a Beniseed (Sesanum indicum L.) Oil Expeller. Ph.D Thesis, Department of Agricultural Engineering, University of Ibadan, Ibadan, Nigeria.

Razavi, S. M. A., S. Yeganehzad and A. Sadeghi (2009).Moisture Dependent Physical Properties of Canola Seeds. J. Agric. Sci. Technol. (2009) Vol. 11: 309-322.

Seifi, M. R. and R. Alimardani (2010). Moisture-Dependent Physical Properties of Sunflower Seed (SHF8190). Journal of Modern Applied Science, Vol. 4, No. 7, 135-143.

Seifi, M., R., Alimardani, R., Akram, A. and A. Asakereh (2010). Moisture-Depend Physical Properties of Safflower (Goldasht). Advance Journal of Food Science and Technology, 2(6): 340-345.

Shafiee, S., Hashemi, J. and K. Kheiralipul (2009). Moisture-Dependent Physical Properties of Castorbean Seed. World Applied Sciences Journal, 7(10): 1216-1221.

Spore (1997). New Crops, New Products. A publication of Technical Centre for Agricultural and Rural Cooperation (CTA), Netherlands, No 68.

Taser, O. F., Altuntas, E. and E. Ozgoz (2005). Physical properties of Hungarian and common Vetch seeds. J. Appl. Sci. 5, 323326.

Tavakoli H., Rajabipour A. and S. S. Mohtasebi (2010)."Moisture-Dependent Some Engineering Properties of Soybean Grains". Agricultural Engineering International: The CIGR Ejournal. Manuscript 1110.Vol. XI. February, 2009. 